\title{
HUBUNGAN GAYA HIDUP DAN POLA MAKAN TERHADAP KEJADIAN SYNDROM DISPEPSIA DI RUMAH SAKIT BHAYANGKARA KOTA MAKASSAR
}

\author{
The Correlation between Lifestyle and Dietary Habits towards Dyspepsia Syndrome Cases in \\ Bhayangkara Hospital Makassar
}

\author{
Ivan Wijaya, ${ }^{1}$ Nur Hamdani $\mathbf{N},{ }^{1,2}$ Herlinda Sari ${ }^{3}$
}

Fakultas Kesehatan Masyarakat Universitas Pancasakti Makassar

Korespondensi : ivanpromkes@gmail.com

\begin{abstract}
ABSTRAK
Penelitian ini bertujuan untuk mengetahui hubungan kebiasaan merokok, hubungan kebiasaan minum beralkohol, hubungan keteraturan makan dan hubungan kebiasaan mengkonsumsi makanan pedas dengan kejadian sindrom dispepsia di Rumah Sakit Bhayangkara Kota Makassar dengan jumlah responden sebanyak 79 orang. Hasil penelitian diperoleh dari hasil survey dengan menggunakan kuisioner. Hasil penelitian ini menunjukkan bahwa tidak ada hubungan kebiasaan merokok dengan kejadian sindrom dispepsia (pvalue $=0,190$ ), Ada hubungan kebiasaan mengkonsumsi minuman beralkohol dengan kejadian sindrom dispepsia (pvalue $=0,040$ ), Ada hubungan kebiasaan konsumsi makanan pedas dengan kejadian sindrom dispepsia (pvalue $=0,000$ ) dan ada hubungan keteraturan makan dengan kejadian sindrom dispepsia di Rumah Sakit Bhayangkara Kota Makassar (pvalue $=0,000$ ). Diharapkan bagi masyarakat untuk memperbaiki gaya hidup dengan tidak merokok dan tidak mengkonsumsi minuman beralkohol dan menjaga pola makan dengan frekuensi makan 3 kali dalam sehari dan mengurangi konsumsi makanan pedas dan bagi pihak rumah sakit untuk melakukan konseling tentang pencegahan sindrom dispepsia kepada penderita, sehingga kejadian ini tidak terulang lagi
\end{abstract}

Kata kunci : Gaya hidup, pola makan, sindrom dyspepsia, merokok, minuman beralkohol, makanan pedas, keteraturan makan

\section{ABSTRACT}

The purpose of this study was to find out the correlation between smoking habits, alcoholic drinking habits, eating regularity, and spicy food consumption habits towards dyspepsia syndrome cases in Bhayangkara Hospital, Makassar in which the total of respondents was 79 people. The results were obtained from the survey using a questionnaire. The results indicated that there was no correlation between smoking habits and dyspepsia syndrome cases ( $p$-value $=0.190)$; there was a correlation between alcoholic drinking habits and dyspepsia syndrome cases ( $p$-value $=0.040)$; there was a correlation between spicy food consumption habits and dyspepsia syndrome cases (p-value $=$ $0.000)$; and there was a correlation between eating regularity and dyspepsia syndrome cases (p-value $=0.000)$. Therefore, the public is expected to improve their healthy lifestyle by not smoking, not consuming alcoholic drinks, and maintaining dietary habits with the frequency of eating 3 times a day. Meanwhile, the hospitals are expected to provide counseling regarding the prevention of dyspepsia syndrome to the patients so that a similar case will not happen anymore.

Keywords: Lifestyle, dietary habits, dyspepsia syndrome, smoking, alcoholic drinks, spicy food, eating regularity 


\section{PENDAHULUAN}

Dispepsia berasal dari bahasa Yunani, yang terdiri dari dua kata yaitu "dys" yang berarti buruk dan "peptei " yang berarti pencernaan. Jadi dispepsia berarti pencernaan yang buruk. Adanya perubahan pada gaya hidup dan perubahan pada pola makan masih menjadi salah satu penyebab tersering terjadinya gangguan pencernaan, termasuk dispepsia. Pola makan yang tidak teratur dan gaya hidup yang cenderung mudah terbawa arus umumnya menjadi masalah yang timbul pada masyarakat. Kecenderungan mengkonsumsi makanan cepat saji dan makanan instan, gaya hidup menjadi lebih sedentary, stres, dan polusi telah menjadi bagian dari kehidupan sehari-hari. Gaya hidup dan kebiasaan makan yang salah akan secara langsung akan mempengaruhi organ-organ pencernaan dan menjadi pencetus penyakit pencernaan (Susilawati, 2013).

Dispepsia adalah suatu kondisi medis yang ditandai dengan nyeri atau rasa tidak nyaman pada perut bagian atas atau ulu hati (Irianto, 2015). Makan yang tidak teratur memicu timbulnya berbagai penyakit karena terjadi ketidak seimbangan dalam tubuh. Ketidak teraturan ini berhubungan dengan waktu makan. Biasanya, ia berada dalam kondisi terlalu lapar namun kadang-kadang terlalu kenyang. Sehingga kondisi lambung dan pencernaannya menjadi terganggu. Faktor yang memicu produksi asam lambung berlebihan, diantaranya beberapa zat kimia, seperti alcohol, umumnya obat penahan nyeri, asam cuka. Makanan dan minuman yang bersifat asam,makanan yang pedas serta bumbu yang merangsang, semua faktor pemicu tersebut dapat mengakibatkan dispepsia (Warianto, 2011 dalam Fitriyana R, 2018).

Pola makan yang tidak teratur, jenis - jenis makanan yang dikonsumsipun yang merangsang peningkatan asam lambung seperti makanan pedas, asam serta minuman beralkohol, kopi dimana kafein yang terdapat pada kopi pada sistem gastrointestinal akan meningkatkan sekresi gastrin sehingga akan merangsang produksi asam lambung. Tingginya asam menyebabkan peradangan serta erosi pada mukosa lambung sehingga dapat memunculkan gangguan dispepsia.

\section{METODE}

Jenis penelitian ini menggunakan survey analitik dengan pendekatan cross sectional yaitu pengukuran variabel dilakukan pada suatu saat untuk menilai hubungan antara variabel independen dengan variabel dependen (Hastono, 2007). Kegiatan yang dilakukan meliputi pengumpulan data dan pengukuran terhadap variabel dependen dan independen. Penelitian ini menganalisis hubungan gaya hidup dan pola makan terhadap kejadian synsdrom dyspepsia di Rumah Sakit Bhayangkara Kota Makassar yang dideskripsikan secara kuantitatif menggunakan data primer dari penyebaran kuisioner dan data sekunder dari profil rumah sakit dan data keperawatan. 
Populasi pada penelitian ini adalah semua pasien yang datang berobat di RS Bhayangkara Kota Makassar sebanyak 451 orang. Penentuan sampel dengan tehnik Simple Random Sampling. Mengingat jumlah populasi cukup banyak, sehingga sampel dalam penelitian ini dapat ditentukan dengan perhitungan Slovin, dengan jumlah sampel sebanyak 79 responden. Pengambilan sampel dengan tehnik pourposive sampling yaitu dengan kriteria Pasien rawat inap 2 x 24 jam

\section{HASIL}

Tabel 1.

Analisis Hubungan Kebiasaan Merokok dengan Kejadian Sindrom Dispepsia

\begin{tabular}{|c|c|c|c|c|c|c|c|}
\hline \multirow{3}{*}{ Kebiasaan Merokok } & \multicolumn{4}{|c|}{ Kejadian Sindrom Dispepsia } & \multirow{2}{*}{\multicolumn{2}{|c|}{ Jumlah }} & \multirow{3}{*}{$\boldsymbol{P}$} \\
\hline & \multicolumn{2}{|c|}{ Menderita } & \multicolumn{2}{|c|}{ Tidak Menderita } & & & \\
\hline & $\mathbf{n}$ & $\%$ & n & $\%$ & $\mathbf{n}$ & $\%$ & \\
\hline Ya & 20 & 25,3 & 13 & 16,5 & 33 & 41,8 & \multirow{3}{*}{0,190} \\
\hline Tidak & 21 & 26,6 & 25 & 31,6 & 46 & 58,2 & \\
\hline Jumlah & 41 & 51,9 & 38 & 48,1 & 79 & 100 & \\
\hline
\end{tabular}

Tabel 1 menunjukkan bahwa berdasarkan kebiasaan merokok responden terlihat bahwa dari 33 responden yang kategori ya, terdapat $20(25,3 \%)$ responden yang menderita sindrom dyspepsia dan 13 (16,5\%) responden yang tidak menderita sindrom

Tabel 2.

Analisis Hubungan Kebiasaan mengkonsumsi Minuman Beralkohol dengan Kejadian Sindrom Dispepsia

\begin{tabular}{|c|c|c|c|c|c|c|c|}
\hline \multirow{3}{*}{$\begin{array}{l}\text { Kebiasaan Konsumsi } \\
\text { Minuman Beralkohol }\end{array}$} & \multicolumn{4}{|c|}{ Kejadian Sindrom Dispepsia } & \multirow{2}{*}{\multicolumn{2}{|c|}{ Jumlah }} & \multirow{3}{*}{$\boldsymbol{P}$} \\
\hline & \multicolumn{2}{|c|}{ Menderita } & \multicolumn{2}{|c|}{ Tidak Menderita } & & & \\
\hline & $\mathbf{n}$ & $\%$ & $\mathbf{n}$ & $\%$ & $\mathbf{n}$ & $\%$ & \\
\hline $\mathrm{Ya}$ & 20 & 25,3 & 10 & 12,7 & 30 & 38,0 & \\
\hline Tidak & 21 & 26,6 & 28 & 35,4 & 49 & 62,0 & 0,040 \\
\hline Jumlah & 41 & 51,9 & 38 & 48,1 & 79 & 100 & \\
\hline
\end{tabular}

Tabel 2 menunjukkan bahwa berdasarkan kebiasaan konsumsi minuman beralkohol responden terlihat bahwa dari 30 dyspepsia. Sedangkan dari 46 responden kebiasaan merokok kategori tidak, terdapat 21 $(26,6 \%)$ responden menderita sindrom dyspepsia dan $25(31,6 \%)$ responden yang tidak menderita sindrom dispepsia.

Kejadian Sind 
tidak menderita sindrom dyspepsia. Sedangkan dari 49 responden kebiasaan konsumsi minuman beralkohol kategori tidak, terdapat
$21(26,6 \%)$ responden menderita sindrom dyspepsia dan $28(35,4 \%)$ responden yang tidak menderita sindrom dispepsia.

Tabel 3.

Analisis Hubungan Kebiasaan Mengkonsumsi Makanan Pedas dengan Kejadian Sindrom Dispepsia

\begin{tabular}{|c|c|c|c|c|c|c|c|}
\hline \multirow{3}{*}{$\begin{array}{c}\text { Kebiasaan Konsumsi } \\
\text { Makanan } \\
\text { Pedas }\end{array}$} & \multicolumn{4}{|c|}{ Kejadian Sindrom Dispepsia } & \multirow{2}{*}{\multicolumn{2}{|c|}{ Jumlah }} & \multirow{3}{*}{$\boldsymbol{P}$} \\
\hline & \multicolumn{2}{|c|}{ Menderita } & \multicolumn{2}{|c|}{ Tidak Menderita } & & & \\
\hline & $\mathbf{n}$ & $\%$ & $\mathbf{n}$ & $\%$ & n & $\%$ & \\
\hline Ya & 38 & 48,1 & 20 & 25,3 & 58 & 73,4 & \multirow{3}{*}{0,000} \\
\hline Tidak & 3 & 3,8 & 18 & 22,8 & 21 & 26,6 & \\
\hline Jumlah & 41 & 51,9 & 38 & 48,1 & 79 & 100 & \\
\hline
\end{tabular}

Tabel 3 menunjukkan bahwa berdasarkan kebiasaan konsumsi makanan pedas responden terlihat bahwa dari 58 responden yang kategori ya, terdapat 38 $(48,1 \%)$ responden yang menderita sindrom dyspepsia dan $20(25,3 \%)$ responden yang tidak menderita sindrom dyspepsia. Sedangkan dari 21 responden kebiasaan konsumsi makanan pedas kategori tidak, terdapat 3 $(3,8 \%)$ responden menderita sindrom dyspepsia dan $18(22,8 \%)$ responden yang tidak menderita sindrom dispepsia.

Tabel 4.

Analisis Hubungan Keteraturan Makan dengan Kejadian Sindrom Dispepsia

\begin{tabular}{ccccccccc}
\hline & \multicolumn{4}{c}{ Kejadian Sindrom Dispepsia } & \multicolumn{2}{c}{ Jumlah } & \multirow{2}{*}{$\boldsymbol{P}$} \\
\cline { 2 - 7 } Keteraturan Makan & \multicolumn{3}{c}{ Menderita } & \multicolumn{2}{c}{ Tidak Menderita } & & \\
\cline { 2 - 7 } & $\mathbf{n}$ & $\mathbf{\%}$ & $\mathbf{n}$ & $\mathbf{\%}$ & $\mathbf{n}$ & $\mathbf{\%}$ & \\
\hline Ya & 8 & 10,1 & 26 & 32,9 & 34 & 43,0 & \\
Tidak & 33 & 41,8 & 12 & 15,2 & 45 & 57,0 & 0,000 \\
\hline Jumlah & $\mathbf{4 1}$ & $\mathbf{5 1 , 9}$ & $\mathbf{3 8}$ & $\mathbf{4 8 , 1}$ & $\mathbf{7 9}$ & $\mathbf{1 0 0}$ & \\
\hline
\end{tabular}

Tabel 4 menunjukkan bahwa berdasarkan keteraturan makan responden terlihat bahwa dari 34 responden yang kategori ya, terdapat $8 \quad(10,1 \%)$ responden yang menderita sindrom dyspepsia dan $26(32,9 \%)$ responden yang tidak menderita sindrom dyspepsia. Sedangkan dari 45 responden dengan keteraturan makan kategori tidak, terdapat $33(41,8 \%)$ responden menderita sindrom dyspepsia dan $12(15,2 \%)$ responden yang tidak menderita sindrom dispepsia. 


\section{PEMBAHASAN}

\section{Hubungan Kebiasaan Merokok dengan Kejadian Sindrom Dispepsia}

Berdasarkan hasil uji Chi Square menunjukkan nilai $\mathrm{p}=0,190$ lebih besar dari $\alpha$ $(0,05)$. Artinya, tidak terdapat hubungan antara kebiasaan merokok dengan kejadian sindrom dispepsia.

Hasil penelitian ini sejalan dengan hasil penelitian yang dilakukan Rahma Nugroho, 2018 yang berjudul Gambaran Karakteristik Pasien Dengan Sindrom Dispepsia Di Puskesmas Rumbai Pesisir Kota Pekan Baru, dimana sebagian besar responden didapatkan perilaku merokok yaitu tidak merokok dengan jumlah 31 orang responden $(59,6 \%)$.

Hasil penelitian menunjukkan bahwa berdasarkan kebiasaan merokok responden terlihat bahwa dari 33 responden yang merokok, terdapat $13(16,5 \%)$ responden yang tidak menderita sindrom dyspepsia, hal ini disebabkan jumlah rokok yang dihisap hanya 1 - 10 batang perhari. Sedangkan dari 46 responden yang tidak merokok, terdapat 21 $(26,6 \%)$ responden menderita sindrom dyspepsia, hal ini disebabkan adanya faktor lain seperti responden mengkonsumsi alkohol $3-4$ kali dalam seminggu.

Efek rokok pada saluran gastrointestinal antara lain melemahkan katup esofagus dan pilorus, meningkatkan refluks, mengubah kondisi alami dalam lambung, menghambat sekresi bikarbonat pankreas, mempercepat pengosongan cairan lambung, dan menurunkan $\mathrm{pH}$ duodenum. Sekresi asam lambung meningkat sebagai respon atas sekresi gastrin atau asetilkolin (Beyer, 2008).

Selain itu, rokok juga mempengaruhi kemampuan cimetidine (obat penghambat asam lambung) dan obat-obatan lainnya dalam menurunkan asam lambung pada malam hari, dimana hal tersebut memegang peranan penting dalam proses ulcerogenesis (timbulnya tukak). Rokok dapat mengganggu faktor defensif lambung (menurunkan sekresi bikarbonat dan aliran darah di mukosa), memperburuk peradangan, dan berkaitan erat dengan komplikasi tambahan karena infeksi $\mathrm{H}$. pylori (Beyer, 2004).

Perokok pasif mempunyai risiko yang sama dengan perokok aktif karena perokok pasif juga menghirup kandungan karsinogen (zat yang memudahkan timbulnya kanker yang ada dalam asap rokok) dan 4.000 partikel lain yang ada diasap rokok, sebagaimana yang dihirup oleh perokok aktif). Setyono Prastowo \& Saryono (2006) rokok menyebabkan penurunan tekanan spingter esofagus bagian bawah sehingga menyebabkan refluk gastroesofagus dan menganggu pengosongan lambung, hal ini menjadikan perokok pasif rentan terhadap kejadian sindrom dyspepsia

\section{Hubungan Konsumsi Minuman Beralkohol Dengan Kejadian Sindrom Dispepsia}

Berdasarkan uji Chi Square menunjukkan nilai $\mathrm{p}=0,040$ lebih kecil dari $\alpha$ $(0,05)$. Artinya, terdapat hubungan antara 
kebiasaan konsumsi minuman beralkohol dengan kejadian sindrom dispepsia.

Hasil penelitian ini sejalan dengan hasil penelitian yang dilakukan Rahma Nugroho, 2018 yang berjudul Gambaran Karakteristik Pasien Dengan Sindrom Dispepsia Di Puskesmas Rumbai Pesisir Kota Pekan Baru, dimana sebagian besar pasien sindrom dispepsia memiliki jenis minuman kelompok iritatif, yaitu 40 orang responden (76,9\%). minuman iritatif antara lain alcohol.

Hasil penelitian menunjukkan bahwa berdasarkan kebiasaan konsumsi minuman beralkohol responden terlihat bahwa dari 30 responden yang mengkonsumsi minuman beralkohol, terdapat $10(12,7 \%)$ responden yang tidak menderita sindrom dyspepsia, hal ini dikarenakan responden hanya mengkonsumsi satu kali dalam seminggu. Sedangkan dari 49 responden yang tidak mengkonsumsi minuman beralkohol, terdapat $21(26,6 \%)$ responden menderita sindrom dyspepsia, hal ini disebabkan faktor lain yaitu pola makan yang tidak teratur.

Alkohol merangsang produksi asam lambung secara berlebihan (meningkatkan faktor agresif), sehingga berakibat negatif pada mukosa lambung (menurunkan faktor defensif). Selain itu, sama seperti rokok, alkohol dapat mengendurkan katup lower esophageal sphincter (LES) sehingga menyebabkan refluks atau berbaliknya aliran asam lambung dan gas ke kerongkongan (Harahap, 2009).
Metabolisme alkohol melibatkan enzim alkohol dehidrogenajse yang terdapat dalam lambung dan hati. Di dalam lambung, sebagian alkohol akan mengalami pemecahan sehingga mengurangi jumlah alkohol yang diserap ke dalam aliran darah hingga 20\%. Alkohol yang diabsorbsi kemudian dibawa melalui pembuluh darah ke hati, yang mampu memecah alkohol dalam jumlah besar. Jumlah alkohol yang dapat ditangani oleh hati sekaligus rata-rata sebanyak 15 gram etanol per jam, bergantung pada ukuran tubuh, kondisi kesehatan, jarak waktu makan atau kondisi lambung dan usus, kebiasaan umum, berat badan, jenis kelamin,dan lain-lain. Bila melebihi jumlah yang dapat dioksidasi oleh hati, alkohol akan dikeluarkan dan masuk sirkulasi darah dan dibawa ke bagian-bagian tubuh yang lain (Almatsier 2002).

\section{Hubungan Konsumsi Makanan Pedas Dengan Kejadian Sindrom Dispepsia}

Berdasarkan hasil uji Chi Square menunjukkan nilai $\mathrm{p}=0,000$ lebih kecil dari $\alpha$ $(0,05)$. Artinya, terdapat hubungan antara kebiasaan konsumsi makanan pedas dengan kejadian sindrom dispepsia.

Hasil penelitian ini sejalan dengan hasil penelitian yang dilakukan Rezky, 2015 pada mahasiswa Fakultas Kedokteran Universitas 
Riau Angkatan 2014 dimana responden dengan frekuensi sering konsumsi makan pedas lebih banyak berjumlah 91 orang $(65,9 \%)$ dibandingkan dengan responden yang jarang makan pedas.

Hasil penelitian ini menunjukkan bahwa berdasarkan kebiasaan konsumsi makanan pedas responden terlihat bahwa dari 58 responden yang mengkonsumsi makanan pedas, terdapat $20(25,3 \%)$ responden yang tidak menderita sindrom dyspepsia, hal ini dikarenakan responden hanya mengkonsumsi makanan pedas setiap makan siang saja. Sedangkan dari 21 responden yang tidak mengkonsumsi makanan pedas, terdapat 3 $(3,8 \%)$ responden menderita sindrom dyspepsia, hal ini disebabkan faktor lain seperti ketidakteraturan makan responden.

Makanan asam dan pedas seperti cabai, merica, dan bumbu-bumbu tajam merupakan makanan yang merangsang organ pencernaan dan secara langsung dapat merusak dinding lambung. Asam dan pedas merangsang sekresi asam lambung berlebihan, sehingga menimbulkan dispepsia. Disamping itu, asam dan pedas juga dapat merangsang peningkatan motilitas atau peristaltik organ pencernaan sehingga dapat memicu timbulnya radang hingga luka pada dinding organ pencernaan (Harahap, 2009).

Konsumsi makanan pedas secara berlebihan akan merangsang sistem pencernaan, terutama lambung dan usus yang berkontraksi. Bila kebiasaan mengkonsumsi lebih dari satu kali dalam seminggu selama minimal enam bulan dibiarkan berlangsung lama dapat menyebabkan iritasi pada mukosa lambung. Selain itu, bubuk cabai atau chilli powder dapat menyebabkan kehilangan sel epitel pada lapisan mukosa (Berdanier, 2008).

Makanan yang berisiko adalah makanan yang terbukti ada pengaruhnya terhadap dispepsia yaitu makanan pedas. Frekuensi makan makanan berisiko berhubungan signifikan dengan kejadian dispepsia. Semakin sering mengkonsumsi makanan tersebut semakin berisiko terkena dispepsia (Anggita, 2012).

\section{Hubungan Keteraturan Makanan Dengan Kejadian sindrom dispepsia}

Berdasarkan hasil uji Chi Square menunjukkan nilai $\mathrm{p}=0,000$ lebih kecil dari $\alpha$ $(0,05)$. Artinya, terdapat hubungan antara keteraturan makan dengan kejadian sindrom dispepsia.

Hasil penelitian ini sejalan dengan hasil penelitian yang dilakukan Astri Dewi, 2017. Dimana terdapat kecenderungan jumlah responden dengan pola makan yang tidak teratur lebih banyak mengalami sindrom dispepsia, yaitu 315 orang (100\%), sedangkan responden dengan pola makan teratur hanya berjumlah 53 orang $(17,8 \%)$. Hasil analisa statistik menggunakan uji korelasi Chi-Square diperoleh hubungan yang bermakna antara keteraturan makan dengan sindrom dispepsia $(\mathrm{p}<0,05)$

Hasil penelitian ini menunjukkan bahwa berdasarkan keteraturan makan 
responden terlihat bahwa dari 34 responden yang frekuensi makan 3 kali dalam sehari yaitu makan pagi, siang dan malam, terdapat 8 $(10,1 \%)$ responden yang menderita sindrom dyspepsia, hal ini disebakan adanya faktor lain yaitu setiap kali makan mengkonsumsi makanan pedas. Sedangkan dari 45 responden dengan frekuensi makan hanya 2 kali dalam sehari yaitu makan siang dan malam, terdapat $12(15,2 \%)$ responden yang tidak menderita sindrom dyspepsia, hal ini disebabkan adanya responden selain makan pokok juga mengkonsumsi makanan selingan.

Kebiasaan makan tidak teratur akan membuat lambung sulit untuk beradaptasi. Jika hal ini berlangsung lama, produksi asam lambung akan berlebihan sehingga dapat mengiritasi dinding mukosa pada lambung sehingga timbul gastritis dan dapat berlanjut menjadi tukak peptik. Hal tersebut dapat menyebabkan rasa perih dan mual. Gejala tersebut bisa naik ke kerongkongan yang menimbulkan rasa panas terbakar (Nadesul, 2005).

Kebiasaan makan yang teratur sangat penting bagi sekresi asam lambung karena kondisi tersebut memudahkan lambung mengenali waktu makan sehingga produksi asam lambung terkontrol. Produksi asam lambung diantaranya dipengaruhi oleh pengaturan sefalik, yaitu pengaturan oleh otak. Adanya makanan dalam mulut secara refleks akan merangsang sekresi asam lambung. Pada manusia, melihat dan memikirkan makanan dapat merangsang sekresi asam lambung (Ganong, 2003).

Frekuensi makan yang tidak teratur, jumlah makan yang tidak sesuai, dan jeda makan yang terlalu lama dapat mencetuskan sindrom dispepsia. Jika proses ini terlalu lama, maka produksi asam lambung akan berlebihan sehingga dapat mengiritasi mukosa lambung dan menimbulkan keluhan berupa mual (Sorong et al., 2013).

Kondisi perut yang kosong berarti terjadi pengosongan pada lambung. Faktor yang berhubungan dengan pengisian dan pengosongan lambung ialah jeda waktu makan dan frekuensi makan. Makan teratur berkaitan dengan frekuensi makan, pola makan, dan jadwal makan. Jadwal makan dapat diinterpretasikan dengan frekuensi makan sehari-hari. Makan yang tidak teratur termasuk meniadakan sarapan pagi menyebabkan pemasukan makanan dalam perut menjadi berkurang sehingga lambung akan kosong. Kekosongan pada lambung dapat mengakibatkan erosi pada lambung akibat gesekan antara dinding-dinding lambung. Kondisi ini dapat mengakibatkan peningkatan produksi asam lambung $(\mathrm{HCl})$ yang akan merangsang terjadinya kondisi asam pada lambung (Susanti, 2011).

\section{KESIMPULAN}

Bedasarkan hasil penelitian dan pembahasan yang telah dikemukakan sebelumnya, maka kesimpulan yang dapat penulis kemukakan adalah sebagai berikut: 
1. Pada variabel kebiasaan merokok didapatkan hasil uji Chi square nilai $p=$ 0,9190 dimana nilai $p>\alpha(0,05)$ berarti tidak ada hubungan antara kebiasaan merokok dengan kejadian sindrom dyspepsia di Rumah Sakit Bhayangkara Kota Makassar

2. Pada varibel kebiasaan mengkonsumsi minuman beralkohol didapatkan hasil uji Chi square nilai $p=0,040$ dimana nilai $p<$ $\alpha(0,05)$ berarti ada hubungan antara kebiasaan mengkonsumsi minuman beralkohol dengan kejadian sindrom dyspepsia di Rumah Sakit Bhayangkara Kota Makassar

3. Pada variabel kebiasaan mengkonsumsi makanan pedas didapatkan hasil uji $C h i$ square nilai $p=0,000$ dimana nilai $p<\alpha$ $(0,05)$ berarti ada hubungan antara kebiasaan mengkonsumsi makanan pedas dengan kejadian sindrom dyspepsia di Rumah Sakit Bhayangkara Kota Makassar

4. Pada variabel keteraturan makan didapatkan hasil uji Chi square nilai $p=$ 0,000 dimana nilai $p<\alpha(0,05)$ berarti ada hubungan antara keteraturan makan dengan kejadian sindrom dyspepsia di Rumah Sakit Bhayangkara Kota Makassar

\section{SARAN}

Berdasarkan hasil penelitian diatas, maka penulis memberikan saran sebagai berikut :

1. Disarankan bagi masyarakat untuk memperbaiki gaya hidup dengan tidak merokok dan tidak mengkonsumsi minuman beralkohol, sehingga sindrom dispepsia dapat dicegah

2. Disarankan bagi masyarakat untuk menjaga pola makan dengan mengurangi konsumsi makanan pedas dan perlunya frekuensi makan 3 kali dalam sehari, sehingga sindrom dispepsia dapat dihindari

3. Disarankan bagi pihak rumah sakit untuk melakukan konseling tentang pencegahan sindrom dispepsia kepada penderita, sehingga kejadian ini tidak terulang lagi

\section{DAFTAR PUSTAKA}

Ambarawati, 2005, Gambaran trait kepribadian, kecemasan dan strees serta strategi coping pada penderita dyspepsia fungsional (tesis) (On-Line), Universitas Indonesia, Jakarta.

Abdullah \& gunawan 2012, Dyspepsia Divisi Gastroenterology Bagian Ilmu Penyakit Dalam fakultas kedokteran universitas Indonesia, Jakarta. vol.39 No.9,

Almatsier S. 2002. Prinsip Dasar Ilmu Gizi. Gramedia Pustaka Utama. Jakarta

Annisa. (2009). Hubungan ketidakteraturan makan dengan sindroma dispepsia remaja perempuan di SMA Plus AlAzhar Medan.

Brun \& kuo, 2010, functional dyspepsia ther adv gastroenterol, Vol.3 NO.3 Hal.145164.

Beyer PL. 2004. Medical Nutrition Therapy for Upper Gastrointestinal Tract Disorders. Di dalam: Mahan $L K$ dan Escott-stump SE, editor. Krause's Food, Nutrition, and Diet Therapy 11th Edition. Philadelphia: Saunders hlm. 686-703.

Berdanier CD, Dwyer J, Feldman EB. 2008. Handbook of Nutrition and Food. Ed II. 
Depkes RI, 2011, Profil kesehatan, kemenkes RI, Jakarta.

Dewi A, 2017, Hubungan Pola Makan Dan Karakteristik Individu Terhadap Sindrom Dyspepsia Pada Mahasiswa Ang.2015 \& 2016 (On-Line) fakultas kedokteran universitas hasanuddin.

Djojoningrat, 2009, Dyspepsia Fungsional, buku ajar ilmu penyakit dalam edisi ke 5, balai penerbit FK UI. Jakarta.

Djojoningrat D. 2001. Dispepsia Fungsional. Di dalam: Sudoyo AW, Setiyohadi B, Alwi I, Simadibrata M, Setiati S, editor. Buku Ajar Ilmu Penyakit Dalam. 3th Ed. Jakarta: Fakultas Kedokteran Universitas Indonesia. Jakarta

Drug dan stanciu, 2007 "functional dyspepsia: recent advance (progresses) in pathophysiology and treatment, a jurnal of clinical medicine, 2 (4) : 311-315 (On-Line).

Dwijayanti H, Ratnasari N, dan Susetyowati. 2008. Asupan Natrium dan Kalium Berhubungan dengan Frekuensi Kekambuhan Sindrom Dispepsia Fungsional. Jurnal Gizi Klinik Indonesia Vol. 5 No 1: 36-40.

Ettinger S. 2000. Macronutrients: Carbohydrates, Proteins, and Lipids. Di dalam: Mahan LK dan Escott-stump SE, editor. Krause's Food, Nutrition, and Diet Therapy 11th Edition. Philadelphia: Saunders hlm. 37-73.(OnLine)

Goshal dkk 2011 “epidemiology of uninvestigated and functional dyspepsia in asia : fact and fiction JNM , 17 (3).

Ganong WF. 2003. Buku Ajar Fisiologi Kedokteran. EGC. Jakarta

Husna, 2016 “hubungan tingkat kekerapan konsumsi kopi dengan kejadian dyspepsia di puskesmas kartasuro (OnLine)

Haag dkk, 2018 "impairment of healthrelated quality of life in functional dyspepsia and chronic liver disease: the influence of depresionand anxienty, aliment pharmacol ther,27:561-571

Harahap, 2010 "karakteristik pasien dyspepsia yang rawat inap di rumah sakit umum sundani medan tahun 2008" (On-Line), fakultas kesehatan masyarakat.Medan.

Harahap, Y. 2009. Karakteristik penderita dispepsia rawat inap di RS Marthara Friska Medan tahun 2007. (On-Line). Fakultas Kesehatan Masyarakat Universitas Sumatera Utara, Medan.

Hardinsyah dan Briawan D. 1994. Penilaian dan Perencanaan Konsumsi Pangan. Jurusan Gizi Masyarakat dan Sumberdaya Keluarga, Fakultas Pertanian, Institut Pertanian Bogor.

Irianto, 2015 "Memahami Berbagai Macam Penyakit, Alfabeta. Bandung

Kaplan dkk,2010 "teori kepribadian dan psikopatologi, synopsis psikiater binarupa aksara publisher, hal 372-394

Khumaidi M. 1994. Gizi Masyarakat. BPK Gunung Mulia. Jakarta

Khomsan A. 2002. Pangan dan Gizi untuk Kesehatan. Jurusan Gizi. Masyarakat dan Sumberdaya Keluarga, Fakultas Pertanian, Institut Pertanian Bogor.

Laksono, 2011 "dyspepsia, retrieved mei 15,2015 , avaitble from chapter II pdfusu institutional repository, usu.ac.id $>$ bitstream (On-Line)

Max Griswold, 2018. Studi: tak ada ukuran “masih aman” bagi alcohol. http://amp-dw.com.

Mudjaddid, 2009 “dyspepsia fungsional, buku ajar: ilmu penyakit dalam edisi ke -5 balai penerbit fk ui hal 10-2109. Jakarta

Micut dkk, 2012 "a review of the psychoemotional factors in functional dyspepsia

Mahadeva, 2006 "epidemiologi of functional didpepsia : a global perspective pubmed, 12(17) : 2661-6266

Nadesul. 2005. Sakit Lambung, Bagaimana Terjadinya. [terhubung berkala]. http://www.kompas.com

Oudenhave dkk,2008 "determinants of symptoms in functional dyspepsia : gastric sensorimotor functional, psychosocial factorsor somatisation? gut, 57:1666-16673.

Purnamasari, L. 2017. Faktor risiko, klasifikasi, dan terapi sindrom dispepsia. Continuing Medical Education, 44(12), 870-873. (On-Line) 
Putheran, A. (2011). Jam piket tubuh manusia. Djogjakarta, Diakses Pada Tanggal 12 Juni 2019

Saad, R. J. \& Chey, W. D. 2006. Review Article: Current and Emerging Therapies for Functional Dispepsia. Aliment Pharmacol Ther; 24: 475-492.

Sudoyo, AW., dkk. 2009. Buku ajar ilmu penyakit dalam; edisi V jilid I. Interna Publising, Jakarta

Susilawati, Palar, S., \& Waleleng, B. J., 2013. Hubungan pola makan dengan kejadian sindrom dispepsia fungsional pada remaja di Madrasa Aliyah Negeri Model Manado. Jurnal Ilmiah Kedokteran Klinik, 1(2), 23-33.

Soo, S., Forman, D., Delaney, B.C., Moayyedi, P. 2004. A Systematic
Review of Psychological Therapiesfor Nonulcer Dispepsia.Am Gastroenterol,99:1817-1822.

Schmidt-Martin,D. andQuigley, E. M. M. 2011. The Definition of Dispepsia. In: Duvnjak M, editor. Dispepsia in Clinical Practice. New York: Springer Science+Business Media. p. 1-8.

Tack, J., Talley, N. J., Camilleri, M., Holtmann, G., Hu, P., Malagelada, J.R., Stanghellini, V. 2006. Functional Gastroduodenal Disorders. Gastroenterology,130:1466-1479.

Wilson LM dan Lester J. 1994. Lambung dan Duodenum. Di dalam: Price SA dan Wilson LM, editor.Patofisiologi. EGC. Jakart 